\title{
ISOLASI DAN IDENTIFIKASI KOMPONEN KIMIA FRAKSI $n$-HEKSANA DAUN TUMBUHAN JERINGAU (Acorus calamus Linn.)
}

\author{
Ari Wahyuni ${ }^{*}$, Abd Kadir ${ }^{* *}$, Ahmad Najib ${ }^{*}$ \\ ${ }^{*}$ Fakultas Farmasi Universitas Muslim Indonesia \\ ${ }^{* *}$ Fakultas Farmasi Universitas Hasanuddin \\ Email : anajib6@gmail.com
}

\begin{abstract}
Isolation and identification of $n$-Hexane faction from Sweet Flag leaves (Acorus calamus Linn.) was done. The aim of research is determine the chemical compound on it leaf, which was commonly used as the traditional medicine. Sample from 250 grams of dried Sweet Flag leaf, macerate using methanol, produce 21.563 grams dried extract. Isolation of $n$-hexane faction using column chromatography method with various mobile phases. The isolate identified by UV and IR spectroscopy method. From the data result show that the isolate has a specific compound.
\end{abstract}

Key words : Isolation, Acorus calamus, UV-Vis, IR

\section{PENDAHULUAN}

Jeringau (Acorus calamus
Linn.) adalah tanaman yang mengandung bahan kimia aktif pada bagian rimpang baik dalam bentuk tepung ataupun minyak yang dikenal sebagai minyak atsiri. Tumbuhan ini mudah tumbuh dan dikembangbiakkan serta tidak beracun bagi manusia, karena secara tradisional banyak digunakan sebagai obat sakit perut dan penyakit kulit, serta dipercaya dapat mengusir pengaruh roh jahat terutama untuk bayi dan balita ${ }^{[1]}$.

Kandungan kimia yang terdapat pada daun Jeringau (Acorus calamus Linn.) adalah flavanoid dan saponin sedangkan rimpangnya mengandung tanin, protein, kalsium oksalat dan minyak atsiri yang mengandung asaron, parasaron, kalamen, asarilaldehid, sesquiterpen, methyleugenol, kalameon, akorin, eugenol, kalamenol, asam n-heptyl, asam akorik ${ }^{[2] . ~ P a d a ~ r i m p a n g ~ t a n a m a n ~}$ adalah minyak atsiri berupa 1,2,4trimetoksi-5-(1-profenil)-benzena atau yang lebih dikenal sebagai asaron ${ }^{[3]}$.

Setiap tumbuhan memiliki komponen kimia yang spesifik dan demikian pula komponen kimia yang terdapat pada tumbuhan Jeringau (Acorus calamus Linn.). Komponen kimia utama (mayor kompound) yang 
terdapat pada tumbuhan ini adalah cis-asaron, trans-asaron $\alpha$-patchoulen, $\beta$-caryophyllen, humulen, metaleugenol, elemicine, cis-0cince ${ }^{[4]}$ yang umumnya terdapat pada rimpangnya, akan tetapi tidak menutup kemungkinan senyawa ini juga terdapat pada bagian lainnya termasuk pada daun.

\section{METODE PENELITIAN}

\section{A. Alat}

Spektroskopi UV-Vis dan Spektroskopi IR

\section{B. Bahan}

Isolasi dan Identifikasi Tumbuhan Jeringau (Acorus calamus Linn.) pada bagian daun dari tumbuhan yang berasal dari kabupaten Pinrang.

\section{Ekstraksi dan Isolasi}

Daun tumbuhan Jeringau (Acorus calamus Linn.) yang telah dikeringkan sebanyak $250 \mathrm{gr}$, dimasukkan ke dalam wadah maserasi kemudian ditambahkan metanol $6000 \mathrm{ml}$ (hingga terendam seluruh permukaan simplisia), lalu ditutup rapat dan dibiarkan selama 5 hari dengan pengadukan sesering mungkin. Setelah itu disaring dan ampas ditambahkan dengan cairan penyari yang baru. Hal ini dilakukan hingga 3 kali, hasil yang di dapat kemudian dipekatkan dengan cara diuapkan dengan Rotavapor hingga diperoleh ekstrak methanol kental sebanyak 21,563 gram. Kemudian ekstrak methanol kental yang diperoleh sebanyak 21,563 gram, diambil sebanyak 10 gram untuk dipartisi dengan pelarut $n$-Heksana dengan cara ekstrak disuspensikan dengan aquades $50 \mathrm{ml}$ lalu dimasukkan ke dalam corong pisah $250 \mathrm{ml}$, kemudian ditambahkan $n$-Heksana sebanyak $50 \mathrm{ml}$ dikocok dan dibiarkan memisah hingga terbentuk dua lapisan. Lapisan $n$ Heksana dipisahkan dari lapisan air. Lapisan air diekstraksi kembali dengan pelarut $n$ - Heksana sebanyak $5 \times 50 \mathrm{ml}$ dilakukan perlakuan yang sama. Lalu fraksi $n$-Heksana yang diperoleh diuapkan dan didapat ekstrak $n$ Heksana kental sebanyak 4,182 gram.

Fraksi $n$-Heksana diisolasi secara kromatografi kolom konvensional dengan fase diam berupa silica gel G.60 (kasar) dan fase gerak menggunakan cairan pengelusi $n$ - Heksana : etil asetat (8:2) pemilihan fase gerak ini didasarkan pada orentasi yang telah dilakukan sebelumnya 
menggunakan kromatografi lapis tipis. Kolom dibuat dengan cara basah, dimana terlebih dahulu kolom dibebas lemakkan dengan dengan cara membilasnya dengan metanol, kemudian sumbat bagian bawah kolom dengan kapas agar silica gel tidak mencemari tampungan fraksi, lalu tabung diisi setengahnya dengan silika gel lalu silika gel dikeluarkan dari dalam tabung dan ditimbang. Silika gel dicampur dengan sebagian eluen yang telah disiapkan kemudian dituangkan ke dalam kolom selama proses tersebut kolom diketuk-ketuk tiap sisinya hingga tidak terbentuk gelembung udara dan diperoleh kerapatan kolom yang seragam, ekstrak yang akan difraksinasi tersebut dimasukkan di atas permukaan silca gel secara merata dan diatas ekstrak tersebut diletakkan kertas saring. Setelah itu eluen dialirkan dan fraksi-fraksi yang diperoleh ditampung pada vial yang disediakan. Fraksi yang diperoleh kemudian di identifikasi dengan

kromatografi lapis tipis dan yang memberikan profil kromatogram yang sama disatukan dalam satu fraksi, dan di dapat IV fraksi.
Fraksi III dari fraksi $n$ Heksana daun jeringau (Acorus calamus Linn.) hasil dari kromatografi kolom ditotolkan pada lempeng KLTP dengan ukuran $10 \times 10 \mathrm{~cm}$, selanjutnya dielusi dalam chamber yang berisi eluen $n$-Heksana : etil asetat (8:2). Jika elusinya sudah mencapai batas, lempeng tersebut dikeluarkan dan dikeringkan di udara kemudian diamati dibawah sinar UV 254 nm dan 366 nm. Lempeng yang telah diamati diberi batas noda dan dikeruk, lalu ditampung pada vial. Hasil kerukan tersebut selanjutnya ditambahkan pelarut methanol kemudian disaring. Filtrat diuapkan lalu ditambahkan kembali dengan pelarut methanol kemudian filtrat ditotolkan pada lempeng KLT, selanjutnya dielusi dengan eluen $n$ Heksana : etil asetat (8:2). Jika proses elusi selesai kemudian diamati di bawah sinar UV 254 nm dan 366 nm. Dan menghasilkan 1 noda tunggal yang menandakan isolat tunggal. 


\section{HASIL PENELITIAN}

Isolasi komponen kimia fraksi $n$-Heksana yang dilakukan secara kromatografi kolom konvensional menggunakan absorben silica gel G.60 dan cairan pengelusi $n$-Heksana : etil asetat (8:2) yang menghasilkan 24 fraksi, profil Kromatografi lapis tipis dapat dilihat pada gambar 2 dan tabel 1. Kemudian fraksi- fraksi digabung berdasarkan profil kromatografi lapis tipis menjadi 4 fraksi, profil kromatogram pada Gambar 1.

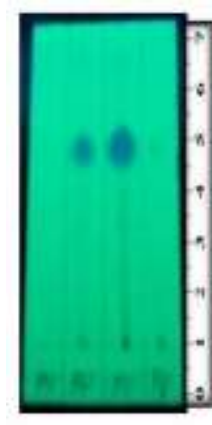

UV 254

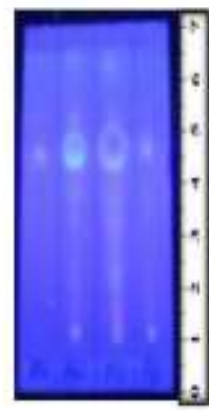

UV 366

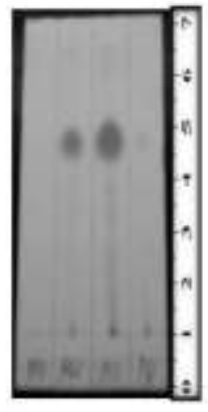

$\mathrm{H}_{2} \mathrm{SO}_{4} 10 \%$
Gambar 1. Foto kromatogram hasil isolasi.

Fraksi III diisolasi lebih lanjut dengan kromatografi lapis tipis preparatif dengan cairan pengelusi $n$ Heksana : etil asetat (8:2) dan terlihat 3 pita pada lampu UV 254 yang kemudian diberi tanda dan dikeruk.

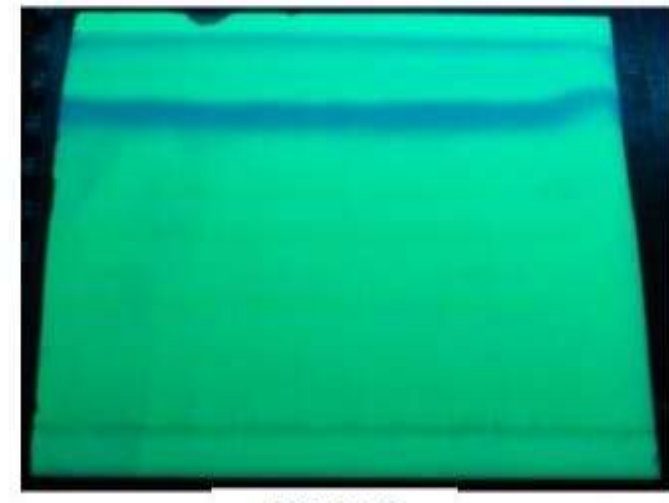

UV 254

Gambar 2. Foto kromatogram fraksi III.

Pengujian lebih lanjut untuk mengetahui kemurnian senyawa yaitu dengan cara kromatografi lapis tipis multi eluen dan cairan pengelusi yang digunakan adalah $n$-Heksana : kloroforom (1:1), $n$ - Heksana : etil asetat (1:6), dan benzen : etil asetat (4:1), dan diperoleh noda tunggal pada masing-masing variasi eluen dan pada penampak noda $\mathrm{H}_{2} \mathrm{SO}_{4} \quad 10 \%$. Selain itu uji kemurnian yang juga dilakukan adalah Kromatografi lapis tipis dua deminsi, yang menggunakan eluen $n$ Heksana : etil asetat (8:2) untuk arah pertama dan eluen $n$ - Heksana : etil asetat (6:4) untuk arah ke dua dan $\mathrm{H}_{2} \mathrm{SO}_{4} \quad 10 \%$ untuk penampak noda yang mana masing-masing memperlihatkan satu noda. Seperti pada Gambar 3 dan 4. 


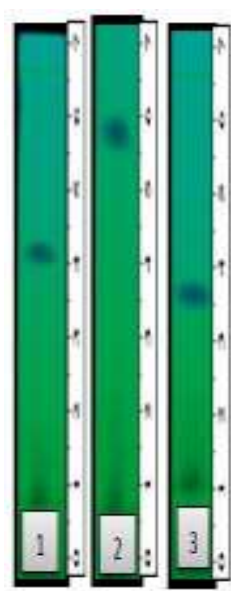

UV 254

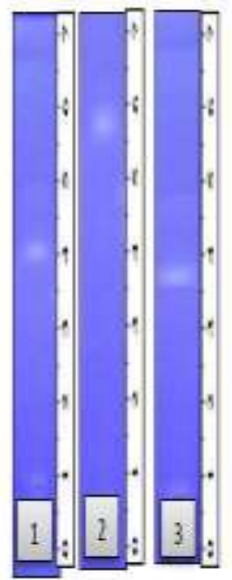

UV 366

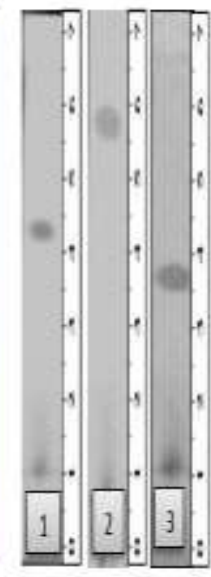

$\mathrm{H}_{2} \mathrm{SO}_{4} \mathrm{HOH}_{\mathrm{H}}$
Gambar 3. Profil Multi Eluen
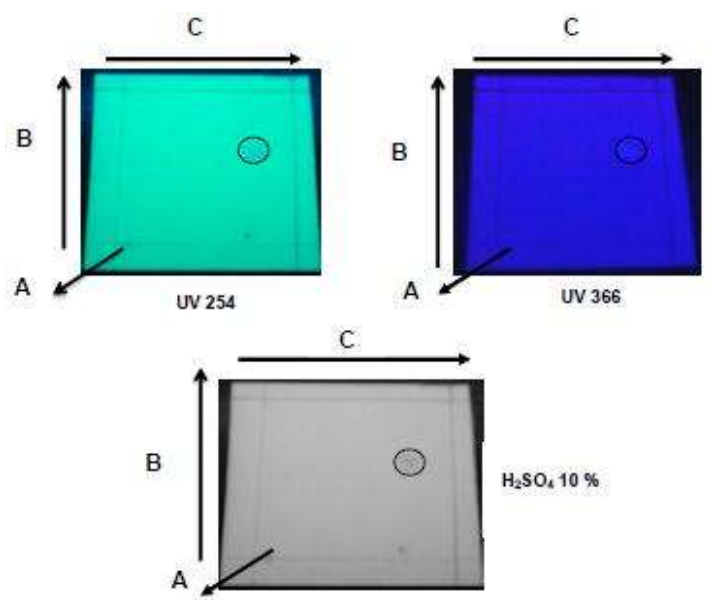

Gambar 4. Profil 2 Dimensi

Interpretasi data spektro UVvisibel menunjukkan serapan maksimum pada panjang gelombang $206 \mathrm{~nm}$ dan serapan tertinggi adalah 1,450 menunjukkan adanya gugus kromofor tunggal Karboksil $(-\mathrm{COOH})$. Sedangkan interpretasi data spectra infra merah menunjukkan pita serapan pada bilangan gelombang ( $\mathrm{u} \mathrm{cm}-1)$ 2925, 2955, 2854 menunjukkan gugus fungsi $\mathrm{C}=\mathrm{C}-\mathrm{H}$ yang diperkuat adanya gugus $\mathrm{C}-\mathrm{H}$ pada pita 722 yang menghasilkan cincin benzen, pada serapan 1734 menunjukkan adanya gugus karbonil (>C=O), pita 1465 merupakan vibrasi $\mathrm{C}=\mathrm{C}$ dengan adanya sistem cincin aromatis, serapan pada 1377, 1366, 1271 menunjukkan adanya ikatan C-
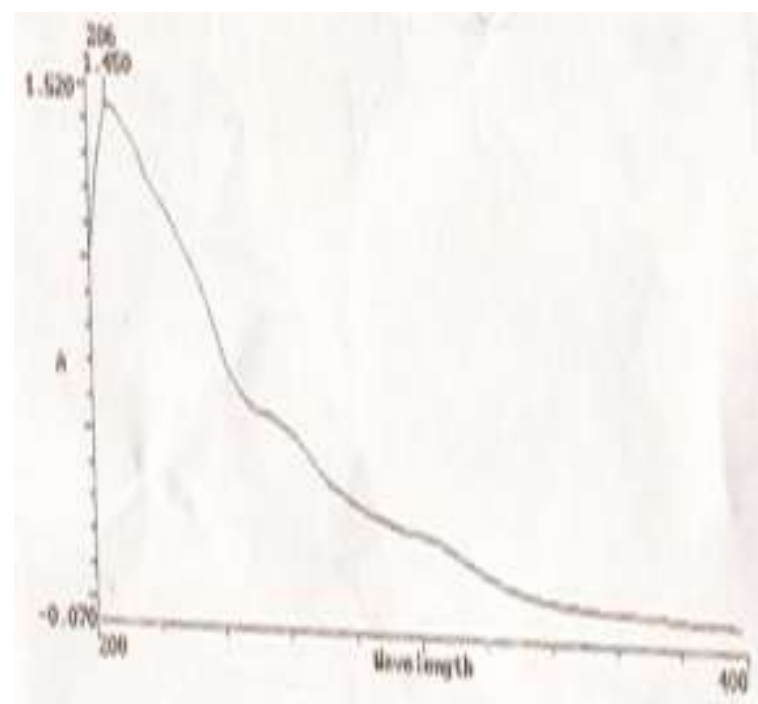

Gambar 5. Spektrum Ultra violet isolat

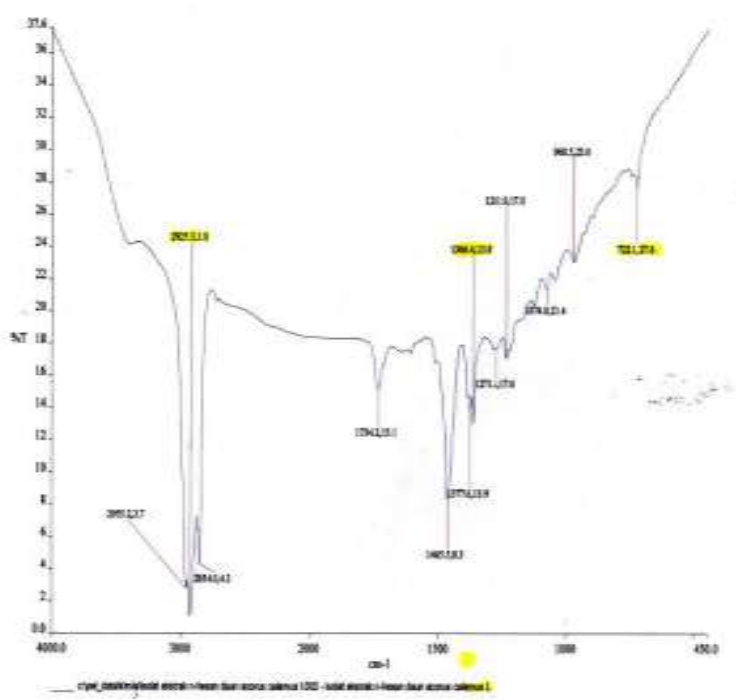

Gambar 6. Spektrum Infra Merah isolat hasil penelitian. 
Berdasarkan hasil penelitian spectrum IR yang kemudian dibandingkan dengan spektrum IR dari beta-asarone (Gambar.7) maka diperoleh hasil sebagai berikut,

\begin{tabular}{ccccc}
\hline No & \multicolumn{2}{c}{ Panjang Gelombang (cm-1) } & $\begin{array}{c}\text { Frekuensi } \\
\text { berdasarkan } \\
\text { literatur }\end{array}$ & Gugus fungsi \\
\cline { 2 - 5 } & Hasil Peneliitian & $\begin{array}{c}\text { Data Spektra IR beta } \\
\text { Asaron }\end{array}$ & $1450-1650$ & $\begin{array}{c}\mathrm{C}=\mathrm{C} \\
\text { (cincin aromatik) }\end{array}$ \\
\hline 1 & 1465 & 1510,1457 & $1450-1810$ & $\begin{array}{c}\mathrm{C}=\mathrm{O} \\
\text { (karbonil) }\end{array}$ \\
\hline 2 & 1737 & 1732,1607 & $1640-1810$ & $\mathrm{C}=\mathrm{C}-\mathrm{H}$ \\
\hline 3 & $2925,2854,2955$ & 2851,2951 & $2850-3000$ & $\mathrm{C}-\mathrm{O}$ \\
\hline 4 & $1271,1377,1366$ & 1210,1036 & $1000-1400$ & $\mathrm{C}-\mathrm{H}$ \\
\hline 5 & 722 & 859 & $690-900$ & \\
\hline
\end{tabular}

Sesuai dengan tabel di atas, diduga bahwa Isolat yang diperoleh merupakan beta asarone dengan melihat perbandingan antara hasil spektra IR dan data spektra IR beta Asaron

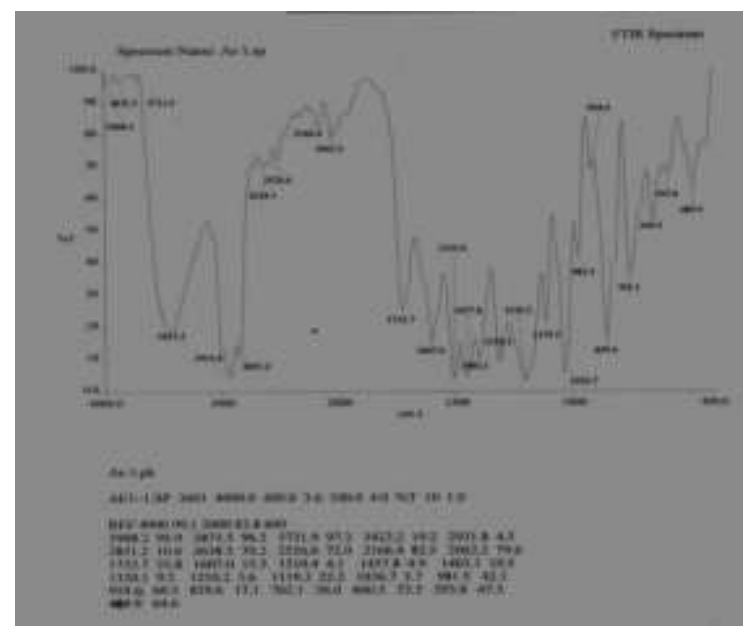

Gambar 7. Spektra IR Beta-asarone* KESIMPULAN

Berdasarkan hasil penelitian yang dilakukan maka dapat disimpulkan bahwa: Isolat yang diperoleh diduga beta asarone dengan melihat perbandingan antara hasil spektra IR dan data spektra IR beta asarone.

\section{DAFTAR PUSTAKA}

Onasis, 2001, Efektivitas

Minyak Rimpang Jeringau ((Acorus calamus Linn.)) Terhadap Kematian Nyamuk Aedes aegypy, (Online) (http://I chapter. pdf. F- 885 .Bab II.html), diakses 30 Maret 2011.

Dharma, A. P., 1985. Tanaman Obat Tradsional Indonesia. Balai Pustaka Jakarta.

Mazza,G. 1985, Gas Chromatographic And Mass Spectrometric Studies Of The Constituen Of The Rhizome Of Calamus. I. The volatile constituents of the essential Oil. Jurnal of chromatography, 328, 179194 Gas Chromatographic And Mass Spectrometric Studies Of The Constituen Of The Rhizome Of Calamus. I. The volatile 
Isolasi Dan Identifikasi Komponen Kimia Fraksi N-Heksana Daun Tumbuhan Jeringau

constituents of the essential

Oil. Jurnal of chromatography, 328, 179194

Agoes, A. 2010. Tanaman Obat Indonesi. Edisi III.

Salemba Medika, Jakarta.

Najib,A., 2010, Isolasi Identifikasi Senyawa Aktif Inhibitor $\alpha$ Glukodase Dari Fraksi NButanol Rimpang Acorus calamus L.,Fakultas Matematika Dan IImu Peng. Alam, Universitas
Indonesia, Program Study Megister IImu Kefarmasian, Depok.

R.Bhuvaneswari and Clellem

Balasundaram "Antibacterial activity of Acorus calamus and some its derivates against fish pathogen Aeromonas hydrophila" Departemen Of Animal Science, School of Life Science, Bharathidasan University, India. 